\title{
ERRATUM TO: THE BLOOD VESSELS DEVELOPMENT, MORPHOGENESIS AND BLOOD CIRCULATION ARE THREE ONTOLOGIC GROUPS HIGHLY UP-REGULATED IN PORCINE OOCYTES BEFORE IN VITRO MATURATION
}

\section{Erratum to:}

The blood vessels development, morphogenesis and blood circulation are three ontologic groups highly up-regulated in porcine oocytes before in vitro maturation

Mariusz J. Nawrocki, Piotr Celichowski, Joanna Budna, Artur Bryja, Wiesława Kranc, Sylwia Ciesiółka, Sylwia Borys, Sandra Knap, Michal Jeseta, Ronza Khozmi, Dorota Bukowska, Paweł Antosik, Klaus P. Brüssow, Małgorzata Bruska, Michał Nowicki, Maciej Zabel, Bartosz Kempisty Advances in Cell Biology 2017 Volume 5, Issue 2, pages 135-142 (DOI: 10.1515/acb-2017-0012)

The number of supporting grant was incorrect. For the reader's convenience, the corrected ACKNOWLEDGEMENTS chapter appears below:

ACKNOWLEDGEMENTS

Not applicable 